\title{
Feeding preferences of the collembolan Onychiurus sinensis for fungi colonizing holm oak litter (Quercus rotundifolia Lam.)
}

Nassima Sadaka-Laulan ${ }^{\mathrm{a}}$, Jean-François Ponge ${ }^{\mathrm{b} *}$, Marie-France Roquebert $^{\mathrm{c}}$, Edith Bury $^{\mathrm{d}}$, Ali Boumezzough $^{\mathrm{a}}$

${ }^{a}$ Faculté des sciences Semlalia, Département de biologie, Laboratoire d'écologie terrestre, Université Cadi Ayyad, boulevard Prince-My-Abdallah, B.P. S/15, 40000 Marrakech, Morocco.

${ }^{\mathrm{b}}$ Laboratoire d'écologie générale, Muséum national d'histoire naturelle, 4, avenue du Petit-Château, 91800 Brunoy, France.

${ }^{\mathrm{c}}$ Laboratoire de cryptogamie, Muséum national d'histoire naturelle, 12, rue Buffon, 75005 Paris, France.

*Corresponding author (fax: +33 1604650 09; e-mail: jean-francois.ponge@wanadoo.fr)

\begin{abstract}
Ten fungi isolated from decaying holm oak leaves (Quercus rotundifolia Lam.) have been presented to the collembolan species Onychiurus sinensis (Hexapoda). The attractiveness and selectivity of the ten fungi was investigated taken into account the effect of the substrate on which the fungus was growing (malt-agar or litter) and the effect of fungal odour. Furthermore, moulting, growth, survival and reproduction of $O$. sinensis in the presence of each of the ten test fungi were studied. Mucor plumbeus and Trichothecium roseum were the most preferred whatever the culture substrate and their odour was the most attractive. Two fungi (Penicillium spinulosum and the Basidiomycete S41) attracted Collembola by their odour but were not preferred as food sources. The animals could survive and reproduce on a mono-diet of several of our test fungi, but not on the Basidiomycete S41 and on Trichoderma polysporum.
\end{abstract}

Collembola / feeding preferences / leaf litter / fungi / fungal odour 
Résumé - Préférences alimentaires du collembole Onychiurus sinensis pour les champignons de la litière de chêne vert (Quercus rofundifolia Lam.). Dix souches fongiques isolées de la litière de chêne vert (Quercus rotundifolia) sont utilisées comme source de nourriture pour le collembole Onychiurus sinensis. L'attrait et la sélectivité de chaque souche sont étudiés en fonction du substrat de croissance (malt-agar ou litière) et de l'odeur du champignon. Parmi les souches testées, Mucor plumbeus et Trichothecium roseum sont les préférées quel que soit le substrat de culture, et leurs odeurs les mieux perçues. En revanche, Penicillium spinulosum et le Basidiomycbte S41 attirent les collemboles par leur odeur, mais sont peu consommés. L'impact de chacune des souches sur les paramètres biologiques du collembole est significatif. La plupart d'entre elles permettent aux individus non seulement de se maintenir, mais aussi de se développer et de se reproduire, à l'exception du Basidiomycète S41 et de Trichoderma polysporum.

\section{Collemboles/ préférences alimentaires / litière / champignon / odeur de champignon}

\section{INTRODUCTION}

Collembola (Hexapoda) used to be considered as unspecialized feeders, based on observations of their gut contents which have been found to include fungal hyphae and spores, bacteria, decaying plant debris, sometimes added with pollen grains, and mineral particles [8, 13, 19, 26, 361. McMillan [25] compared the gut contents of three Onychiurid collembolan species with a random image of their immediate environment (artificial guts). He concluded that there was a poor degree of specialization in the food of Collembola, at least in the Onychiuridae family.

Nevertheless, several studies gave a prominent place to fungi in the diet of Collembola $[2,22,30,32,33$, 34]. It became increasingly evident that some feeding specificity actually exists in these microarthropods. This has been demonstrated experimentally by Farahat [12], Visser and Whittaker [41], Leonard [24], Bengtsson et al. [6], Shaw [37], Klironomos et al. [21] and Bardgett et al. [3]. Despite this research, the diets of most Collembola in the field remain poorly understood. For instance, even though fungal hyphae seem to be favoured in the field by the collembolan Tomocerusflavescens (= Pogonognathellus flavescens), fungal spores were preferred when this species was grown in the laboratory [22]. Not all ingested food is completely assimilated and some components of the food bolus may even be toxic. Kilbertus and Vannier [20] isolated three fungal species from the gut contents of field- 
collected T. minor. From these three fungi, only one allowed a normal development of individuals when fed on fungus only, whereas the other two were detrimental to their growth and fecundity.

Factors explaining the palatability of a given fungus are still unknown, although suggestions have included: (i) a relatively poor density of some mycelial wefts which allows animals to move here and there more easily [28]; (ii) the senescence stage of fungal colonies [30]; and (iii) the nutritional value of the strain, or more especially its nitrogen content $[9,24]$. For these animals, odour seems to be a useful clue for selecting some fungal species $[4,5$, 15], as are toxic metabolites [41].

Most of the experiments on food preferences of Collembola were achieved using pure fungal cultures on standard media such as malt-agar, potato-dextrose-agar and Czapek-Dox-agar. However, it is known that these preferences are affected by the nature of the medium used for the fungus culture [17, 21, 24], which may be due to changes in the spectrum of volatile compounds emitted by the fungus $[4,5,9]$. Our purpose was to answer the following questions:

1) Is Onychiurus sinensis (Collembola: Onychiuridae) attracted to fungi commonly occurring in the litter of holm oak (Quercus rotundifolia Lam.) which constitutes its natural habitat? If yes, which species are preferred?

2) Do these preferences differ according to the medium onto which the fungus has been cultured (malt-agar or sterilized litter)?

3) Is odour a stimulus for the observed choices, if any?

4) Are these preferences reflected in survival rate, fecundity and growth of the animals when these are given a single-fungus diet?

\section{MATERIALS AND METHODS}

Four experimental series were designed, in which springtails were placed in the presence of:

1) A fungal strain previously grown on malt-agar (preference tests using fungus only). 
2) A disk of leaf litter, sterilized by autoclaving then inoculated with a test fungus, compared with a control disk, of the same origin but neither sterilized nor inoculated (preference tests using litter).

3) A disk of filter paper (cellulose), impregnated with the odour of a test fungus, compared with a control disk, neutral (attraction/repulsion tests using fungal odour).

The duration of the above-mentioned experiments was $3 \mathrm{~h}$.

4) The animals which had been used in the first experimental series (preference tests using fungi only) were then followed daily during 9 weeks on the same substrate (fourth series) in order to estimate the nutritional value of each fungal strain, by measuring several biological parameters: moulting rate, oviposition rate, survival rate, and linear growth (nutritional tests).

\subsection{Collembola}

Tests used Onychiurus sinensis Stach, which lives in holm oak litter (Quercus rotundifolia Lam.) in Toufliht (higher Atlas of Marrakech, Morocco). Animals were extracted in Berlese funnels, then cultured on a mixture of plaster of Paris and charcoal on an algal diet (Pleurococcus).

Individuals were starved for $2 \mathrm{~d}$ before the start of each experiment. Only young adults were used because at this stage, which is the start of sexual maturity, animals still have a high growth rate and a higher feeding activity than younger or older individuals [16]. The mean overall length $( \pm S E)$, measured with a reticle eye-piece on a batch of fifty individuals, was $1.36+0.01 \mathrm{~mm}$. We did not observe any increase in body length after this young adult stage. After the starvation period, twenty young adult individuals were transferred to a bottomless plastic cylinder (1 $\mathrm{cm}$ diameter) placed at the centre of a Petri dish $(5.6 \mathrm{~cm}$ diameter $)$ which had been partly filled with a mixture of plaster of Paris and charcoal.

After preparation of the dishes (five replicates for each fungal strain and each substrate), the plastic cylinder was removed, whereafter observations were made every $10 \mathrm{~min}$ for $3 \mathrm{~h}$. Animals that were present on the test (fungus, litter, filter paper) or on the control substrate and on the corresponding sector but not on the substrate were counted separately. A diameter line drawn on the cover lid was used to divide the Petri dish into two sectors of equal 
size. When over or under $50 \%$ of the animals were present in a given sector, this indicated that something in this sector might be attractive or repulsive for the animals, respectively. During the experimental run, dishes were kept in darkness, because it was observed that the studied animals avoided light. Mean numbers of animals present in the two sectors of experimental boxes were compared by t-tests [39]. In order to avoid artefacts due to negative correlations between the two sectors, differences between sectors were compared to a theoretical null value (absence of attractiveness or repulsion by the fungus). Mean numbers of animals present on test substrates (litter disks, filter paper) in the two sectors were compared using the same procedure, as well as the mean number of animals present on a conditioned substrate or a piece of agar culture with the rest of the sector. Attractiveness of the different fungal species was compared by one-way ANOVA [39] using mean numbers of animals present on the corresponding pieces of culture or conditioned substrates.

Boxes used for preference tests using fungi only (first experimental series) were maintained so as to culture the animals over 9 weeks. Pieces of fungal culture (avoiding agar) were deposited into the dishes as often as they were consumed. Animals, moults and eggs were counted daily. The body length of each surviving individual was measured at the end of the experiment. Data were analysed by one-way ANOVA [39]. Means were compared between fungal strains using the Newman-Keuls test [39]. The capability of the different fungal species to ensure both growth, survival and reproduction of $O$. sinensis, was estimated by ranking the strains for each biological parameter. Ranks were summed up in order to classify the fungal species into several groups.

\subsection{Fungi}

Fungal strains were isolated from holm oak leaf litter, then grown on malt-agar at $295 \mathrm{~K}$ (22 “C), and regularly sub-cultured.

A preliminary inventory of the litter-inhabiting fungal flora furnished a list of species, most of them are commonly found in deciduous as well as coniferous or herb litter. Despite this evident lack of specificity, we selected the following strains, which can be considered as most frequent, in terms of fungal propagules, in the studied litter:

Dematiaceous fungi: 


\author{
Alternaria alternata (Fr.) Keissler \\ Aureobasidium pullulans (de Bary) Arnaud \\ Cladosporium cladosporioides (Fr.) de Vries \\ Epicoccum purpurascens Ehr. ex Schlecht \\ Trichothecium roseum (Pers.) Link ex Gray
}

Sterile dark mycelium S 18

Hyaline fungi:

\author{
Mucor plumbeus Bon. \\ Penicillium spinulosum Thom \\ Trichoderma polysporum (Link ex Pers.) Rifai \\ Basidiomycete S41
}

According to the experimental series fungal strains were tested as:

1) Pieces of mycelium $6 \mathrm{~mm}$ in diameter, picked up at the border of cultural colonies, avoiding agar which otherwise would be heavily consumed by the animals (preliminary observations); only young (8-10-d-old) cultures were used;

2) Disks of leaf litter $6 \mathrm{~mm}$ in diameter, autoclaved then inoculated with the test fungi and incubated at $295 \mathrm{~K}$ $\left(22{ }^{\circ} \mathrm{C}\right)$ until visible fungal development;

3) Disks of cellulose filter paper, impregnated with fungal odour; for this purpose, disks were appressed to the cover lid inside of boxes used for the culture of fungal strains, during a period of $20 \mathrm{~d}$; they were checked for the absence of visible fungal development.

\title{
3. RESULTS
}


Figures $1-3$ show examples of the course of changes observed in the distribution of animals during experimental runs. We selected two fungi indicating strong effects (attraction and repulsion) by the fungus, and one intermediary case.

\subsection{Fungal mycelium grown on malt-agar (table I, figures 1-3)}

O. sinensis consumed all but one (T. polysporum, figure 3) test fungi, at a varying rate according to species. The mean number of animals present on the mycelium varied significantly from 14.8 for M. plumbeus and 13.1 for $T$. roseum to 5.8 for $C$. cladosporioides and only 0.1 for T. polysporum (one-way ANOVA, F $=56.95, \mathrm{P}<0.001$ ).

Using the mean number of animals which had been found directly on a strain at a given time, we can classify the fungi in a decreasing order of preference: M. plumbeus $>$ T roseum = sterile dark mycelium S18 $>$ A. alternata $>$ A. pullulans $=$ P. spinulosum $>$ C. cladosporioides $=$ E. purpurascens $=$ Basidiomycete S41 $>T$ polysporum. For more information on the significance of differences between fungal strains, results of a posteriori Newman-Keuls tests were presented in table I.

The number of animals in the sector with the fungal culture was largely more than ten, thus indicating an attraction by the fungus, with the exception of Basidiomycete S41 and T polysporum (figure 3). The latter seemed to be actively repulsive to the animals, unlike Basidiomycete S41. Attraction was often perceptible within the first 10 min. In a number of cases (sterile dark mycelium S 18, A. alternata, A. pullulans, C. cladosporioides and E. purpurascens), the number of animals in the sector with fungi was high from the first 10 min onwards, despite a poor increase (or no increase at all) in the number of animals in direct contact with the fungal culture, thus indicating that attraction and consumption were not necessarily correlated.

\subsection{Inoculated litter disks (table I, figures 1-3)}

The mean number of animals found on inoculated litter disks decreased significantly from 18.3 for $T$ roseum, 18.2 for C. cladosporioides, and 17.6 for M. plumbeus to 2 for $T$. polysporum (one-way ANOVA, F = 144.77, $\mathrm{P}<0.001$ ), with the following order of preference: $T$. roseum $=$ C. cladosporioides $=$ M. plumbeus $=E$. 
pulpurascens $>$ Basidiomycete $\mathrm{S} 41>$ A. pullulans $>$ A. alternata $>$ sterile dark mycelium $\mathrm{S} 18=P$. spinulosum $=T$. polysporum. Thus when grown on a litter substrate (natural habitat of $O$. sinensis), animals did not exhibit the same order of preference for fungal strains than when the latter were grown on malt-agar.

In all cases, a low number or no animals at all were found on uninoculated litter disks. Attraction and consumption were better correlated than in the first experimental series, the two curves (sector and direct contact) being always parallel. No repulsive effect of litter disks inoculated with T. polysporum was registered.

\subsection{Odour-impregnated paper disks (table I, figures 1-3)}

The most attractive odours were those of T. roseum (3.4 animals), E. purpurascens (2.6), P. spinulosum (2.3), Basidiomycete S41 (2. 1), M. plumbeus (1.9) and the sterile dark mycelium S18 (1.8). Although these numbers were low compared to the number of animals found on fungal mycelia growing on agar or litter disks, comparison between odour-impregnated and neutral paper disks and between sectors where these substrates were present allowed to conclude that odour played a role in the choice of fungal strains by $O$. sinensis. Nevertheless strong discrepancies in differences between sectors were observed according to fungal strain (one-way ANOVA, $\mathrm{F}=34.64, \mathrm{P}<0.001$ ). Among the preferred odours, that of P. spinulosum, M. plumbeus and the sterile dark mycelium S18 seemed to be perceived more easily than that of $T$. roseum, E. purpurascens and the Basidiomycete S41, animals being more abundant in the sector with odour-impregnated disk in the first group only.

T. roseum seemed to be attractive whatever the substrate used. In contrast, $T$ polysporum always seemed repulsive to the animals. The latter strain was the only one displaying a lower number of animals in its own sector (figure 3).

\subsection{Impact of fungal diet on survival, growth and reproduction of $O$. sinensis (table II)}

Species-specific effects of fungal strains were registered on four selected biological parameters. Although not heavily consumed (but rather attractive by its odour, table I), E. purpurascens maximized moulting and growth rates. On the contrary, these life history features were minimal on $T$ polysporum and on Basidiomycete S41, although the 
latter seemed attractive by its odour (table I). The highest oviposition rate was found for animals cultured on $M$. plumbeus, A. pullulans and on the sterile dark mycelium S18, while there was no oviposition on Basidiomycete S41 and on $T$ polysporum.

Based on their stimulatory or inhibitory effect on the four measured parameters, estimated by ranking fungal strains (see Materials and Methods and table II), three groups of test fungi can be identified. The first group is composed of E. purpurascens, T. roseum, M. plumbeus, A. pullulans and the sterile dark mycelium S18. All of them were favourable to both growth and reproduction of $O$. sinensis. A second group is composed of $P$. spinulosum, A. alternata and C. cladosporioides. These fungi can have a favourable effect on either growth or reproduction, but not on both, thus when given alone they do not constitute a sufficient food diet. The survival rate was high (at least $90 \%$ for 9 weeks) for both groups. The third group is composed of Basidiomycete S41 and T. polysporum. These two strains had the lowest egg production, growth, and to some extent moulting. Only half the animals survived after 9 weeks. Thus, fungi of the third group can be considered as toxic for $O$. sinensis, at least when grown on malt-agar.

\section{DISCUSSION}

A food substrate can be considered to be favourable to a given species when it not only allows the survival, growth, and reproduction of adults, but when it also results in a new cohort which will grow and reproduce. During the 9-week culturing experiment, we noted a very low mortality of juveniles (around $1 \%$ ), which means that, except for the two probably toxic strains, T. polysporum and Basidiomycete S41, most fungi were a food source for $O$. sinensis, and may compose at least part of its natural food. Such a wide range of tolerance when animals are constrained to eat on a single fungus has been already shown by Ponge and Charpentié [33] for the collembolan Pseudosinella alba. The attractiveness of all fungal strains, except $T$ polysporum, to $O$. sinensis indicates that (i) fungi are a prominent food source for this animal, and (ii) that $O$. sinensis is able to satisfy its food requirements from a great variety of fungal species. This capability of using a wide range of food sources may be important for the survival of fungus-eating species, as most litter fungi are not available throughout the year $[14,18]$, or when a given animal species competes in the same niche with other fungivorous fauna [1]. Nevertheless, the sterile Basidiomycete S41 does not fit this scheme since it seems to have no nutritional value, despite its strong attractiveness to $O$. sinensis. 
In our tests, $O$. sinensis exhibited marked preferences for some fungi which had been isolated from holm oak litter. Nevertheless, dematiaceous fungi (with dark hyphae and conidiospores) were not systematically preferred to hyaline fungi, contrary to results from other studies on fungivorous springtails and mites [21, 28, 29, 34, 41]. We suspect such preferences to be not only species-specific, since results of preference tests varied according to the substrate (agar piece, inoculated litter, odour-impregnated filter disk). In our experiments, this substrate effect was clearly visible for $C$. cladosporioides, E. purpurascens and Basidiomycete S41, which were preferred only when inoculated on litter, while A. alternata, the dark sterile mycelium S18 and P spinulosum were preferred only when grown on malt-agar. T. roseum and M. plumbeus were attractive, whatever their growth substrate. It should be noted too that $T$ polysporum, although the less preferred fungus, was better accepted on litter. Such discrepancies according to culture substrate can be explained by changes in spore production and fungal biochemistry. Malt-agar favours conidiogenesis of most moulds [38]. Conversely, in litter substrates, the high content in carbon dioxide which is found at the inside of decaying leaves impedes conidiogenesis [31]. Leonard [24] showed that the order of preferences of the collembolan Folsomia candida for three saprophytic fungi depended on the nature of the culture medium and that in the long term, laboratory strains might diverge chemically from strains recently isolated from the soil. Reinforcing this view, Bengtsson et al. [4, 5] demonstrated that volatile compounds produced by three fungal species varied whether they had been grown on malt-agar or on sterilized soil, which influenced their rate of consumption by the collembolan Onychiurus armatus (= Protaphorura armata).

Concerning fungal toxicity, our results pointed to deleterious effects of the genus Trichoderma, at least in the long term (no growth, no reproduction, higher mortality rate). Ponge and Charpentié [33] showed that Trichoderma harzianum and Gliocladium deliquescens were not consumed by the collembolan Pseudosinella alba and that reproduction of the animals ceased. Both are moulds whose spores are covered with a slimy stuff. Elsewhere, Miller and Anagnostakis [27] demonstrated that Trichoderma viride was toxic to nematodes. Trichoderma and Gliocladium species are known to produce compounds such as gliotoxin which are toxic to other fungi $[10,11]$. Although we did not test the toxicity of this compound against $O$. sinensis, we suspect that it was responsible for the antagonistic effects observed on soil animals as well. Nevertheless, effects other than toxic compounds can be suspected, since T. roseum, one of the most preferred fungi (and highly favourable to growth and reproduction of $O$. sinensis) in the present study, is also well-known for its wide range of toxicity towards animals and fungi [35, 42]. In this case, we cannot exclude the possibility of intra-species variation [31], some strains of this 
fungus being possibly toxic, others not.

Results from the second experimental series proved that fungi are not only an important food source for $O$. sinensis, but that they were clearly preferred to litter itself. After 3-h observation, the surface of nearly all litter disks had been cleared of fungi but the litter disks themselves were intact. Thus, when these animals consume decaying litter coming from their natural habitat (unpubl. data), we can suspect that this is more due to the increasing fungal content of litter in the course of decomposition [7] than to a decrease in its mechanical resistance.

The number of animals present on the fungal mycelium (first experimental series) was always low at the beginning (except for M. plumbeus and T. roseum), and then increased steadily (figure 2). This increase could be due either to a perception of the fungal odour by each individual, or to an aggregative behaviour using pheromones as an attractant. The latter has been demonstrated for several members of the family Entomobryidae [23, 40]. In none of the experiments, we observed such aggregative behaviour for $O$. sinensis, but the individuals seemed to move at random and independently of each other. Although no aggregative behaviour has been observed, its absence could be due to a masking effect of fungal odour against aggregation pheromones, or to the fact that different individuals do not perceive fungal odour with the same acuteness. Tests using filter paper disks impregnated with fungal odour (third series) revealed that attraction towards fungi was at least partly mediated by olfactive stimuli. Mostly, the number of animals in the sector occupied by the odour-impregnated disk was higher than in the control sector. However, the presence of animals on the paper disk itself was low. We conclude that the olfactive stimulus needs to be supported by the presence of the fungus (and eventually its consumption) to ensure that animals cease their wandering movements. Thus fungal odour undoubtedly helps fungal-eating Collembola to find and select fungi more rapidly than at random $[4,5]$, but its intensity as a stimulus for eating fungi is probably weak. When a fungal strain is consumed, thus when animals remain motionless on a fungal colony, possibly found randomly as well, selfreinforcing processes associated to food consumption (and probably taste perception) probably act at a higher intensity than odour itself.

\section{REFERENCES}

[1] Anderson J.M., Competition between two unrelated species of soil Cryptostigmata (Atari) in experimental 
microcosms, J. Anim. Ecol. 47 (1978) 787-803.

[2] Arpin P., Kilbertus G., Ponge J.F., Vannier G., Importance de la microflore et de la microfaune en milieu forestier, in: Pesson P. (Ed.), Actualités d'écologie forestière, Gauthier-Villars, Paris, 1980, pp. 87-150.

[3] Bardgett R.D., Whittaker J.B., Frankland J.C., The diet and food preferences of Onychiurus procampatus (Collembola) from upland grassland soils, Biol. Fertil. Soils 16 (1993) 296-298.

[4] Bengtsson G., Erlandsson A., Rundgren S., Fungal odour attracts soil Collembola, Soil Biol. Biochem. 20 (1988) 25-30.

[5] Bengtsson G., Hedlund K., Rundgren S., Selective odor perception in the soil Collembola Onychiurus armatus, J. Chem. Ecol. 17 (1991) 2113-2125.

[6] Bengtsson G., Ohlsson L., Rundgren S., Influence of fungi on growth and survival of Onychiurus armatus (Collembola) in a metal polluted soil, Oecologia 68 (1985) 63-68.

[7] Berg B., Söderström B., Fungal biomass and nitrogen in decomposing Scats pine litter, Soil Biol. Biochem. 11 (1979) 339-341.

[8] Bödvarsson H., Alimentary studies of seven common soil inhabiting Collembola of southern Sweden, Entomol. Scand. 1 (1970) 74-80.

[9] Booth R.G., Anderson J.M., The influence of fungal food quality on the growth and fecundity of Folsomia candida (Collembola: Isotomidae), Oecologia 38 (1979) 317-323.

[10] Dennis C., Webster J., Antagonistic properties of species-groups of Trichoderma. I. Production of non-volatile antibiotics, Trans. Brit. Mycol. Soc. 57 (1971) 25-39.

[11] Dennis C., Webster J., Antagonistic properties of species-groups of Trichoderma. II. Production of volatile antibiotics, Trans. Brit. Mycol. Soc. 57 (1971) 41-48.

[12] Farahat A.Z., Studies on the influence of some fungi on Collembola and Atari, Pedobiologia 6 (1966) 258-268.

[13] Gilmore S.K., Raffensperger E.M., Foods ingested by Tomocerus spp. (Collembola, Entomobryidae) in relation 
to habitat, Pedobiologia 10 (1970) 135-140.

[14] Gourbière F., Structure spatio-temporelle de la mycoflore des premiers stades de décomposition des aiguilles d'Abies alba, Soil Biol. Biochem. 20 (1988) 453-458.

[15] Hedlund K., Bengtsson G., Rundgren S., Fungal odour discrimination in two sympatric species of fungivorous collembolans, Funct. Ecol. 9 (1995) 869-875.

[16] Johnson D.L., Wellington W.G., Dispersal of the Collembolan Folsomia candida Willem, as a function of age, Can. J. Zool. 61 (1983) 2534-2538.

[17] Kaneko N., McLean M.A., Parkinson D., Grazing preference of Onychiurus subtenuis (Collembola) and Oppiella nova (Oribatei) for fungal species inoculated on pine needles, Pedobiologia 39 (1995) 538-546.

[18] Kendrick W.B., Burges A., Biological aspects of the decay of Pinus silvestris leaf litter, Nowa Hedwigia 4 (1962) 3 13-344 + 14 inlet plates.

[19] Kilbertus G., Vannier G., Microbial analysis and weight estimation of feces produced by four sympatric Collembola species in forest litter, Rev. Ecol. Biol. Sol 16 (1979) 169-180.

[20] Kilbertus G., Vannier G., Relations microflore-microfaune dans la grotte de Sainte-Catherine (Pyrénées ariégeoises). II. Le régime alimentaire de Tomocerus minor (Lubbock) et Tomocerus problematicus Cassagnau (Insectes Collemboles), Rev. Ecol. Biol. Sol 18 (1981) 3 19-338.

[21] Klironomos J.N., Widden P., Deslandes I., Feeding preferences of the collembolan Folsomia candida in relation to microfungal successions on decaying litter, Soil Biol. Biochem. 24 (1992) 685-692.

[22] Knight C.B., Angel R.A., A preliminary study of the dietary requirements of Tomocerus (Collembola), Am. Midl. Nat. 77 (1967) 510-517.

[23] Krool S., Bauer T., Reproduction, development and pheromone secretion in Heteromurus nitidus Ternpleton, 1835 (Collembola, Entomobryidae), Rev. Ecol. Biol. Sol 24 (1987) 187-195.

[24] Leonard M.A., Observation of the influence of culture conditions on the fungal feeding preferences of Folsomia candida (Collembola: Isotomidae), Pedobiologia 26 (1984) 361-367. 
[25] McMillan J.H., Interspecific and seasonal analyses of the gut contents of three Collembola (Family Onychiuridae), Rev. Ecol. Biol. Sol 12 (1975) 443-457.

[26] McMillan J.H., Healey I.N., A quantitative technique for the analysis of gut content of Collembola, Rev. Ecol. Biol. Sol 8 (1971) 295-300.

[27] Miller P.M., Anagnostakis S., Suppression of Pratylenthus penetrans and Tylenchorhynchus dubius by Trichoderma viride, J. Nemat. 9 (1977) 182-183.

[28] Mills J.T., Sinha R.N., Interactions between a springtail, Hypogastmra tullbergi, and soil-borne fungi, J. Econ. Entomol. 64 (1971) 398-401.

[29] Mitchell M.J., Parkinson D., Fungal feeding of oribatid mites (Acari: Cryptostigmata) in an aspen woodland soil, Ecology 57 (1976) 302-312.

[30] Moore J.C., Ingham E.R., Coleman D.C., Inter-and intraspecific feeding selectivity of Folsomia candida (Willem) (Collembola, Isotomidae) on fungi, Biol. Fertil. Soils 5 (1987) 6-12.

[31] Moore-Landecker E., Fundamentals of the fungi, 3rd ed., Prentice Halls, Englewood Cliffs, 1990.

[32] Ponge J.F., Food resources and diets of soil animals in a small area of Scots pine litter, Geoderma 49 (199 1) 3362.

[33] Ponge J.F., Charpentié M.J., Etude des relations microflore-microfaune: expériences sur Pseudosinella alba (Packard), Collembole mycophage, Rev. Ecol. Biol. Sol 18 (1981) 291-303.

[34] Poole T.B., Studies on the food of Collembola in a Douglas fir plantation, Proc. Zool. Sot. Lond. 132 (1959) 7182.

[35] Richards N.T., Trichothecin revisited? Mycologist 2 (1988) 123-124.

[36] Saur E., Ponge J.F., Alimentary studies on the Collembolan Paratullbergia callipygos using transmission electron microscopy, Pedobiologia 31 (1988) 355-379.

[37] Shaw P.J.A., A consistent hierarchy in the fungal feeding preferences of the Collembola Onychiurus armatus, 
Pedobiologia 31 (1988) 179-187.

[38] Smith G., An Introduction to Industrial Mycology, Edward Arnold, London, 1969.

[39] Sokal R., Rohlf F.J., Biometry, 3rd ed., Freeman, 1995.

[40] Verhoef H.A., Nagelkerke C.J., Joosse E.N.G., Aggregation pheromones in Collembola (Apterygota), a biotic cause of aggregation, Rev. Ecol. Biol. Sol 14 (1977) 21-25.

[41] Visser S., Whittaker J.B., Feeding preferences for certain litter fungi by Onychiurus subtenuis (Collembola), Oikos 29 (1977) 320-325.

[42] Wyllie T.D., Morehouse L.G., Mycotoxic Fungi, Mycotoxins and Mycotoxicoses, vol. 1, Dekker Marcel, New York, 1977. 


\section{Legends of figures}

Figure 1. Mucor plumbeus. Distribution of twenty individuals of Onychiurus sinensis in a Petri dish divided into a fungal sector and a fungal-free control sector. In the fungal sector, the fungus was present as a colony previously grown either on malt-agar or on a litter disk, or as a fungal-odour impregnated filter paper disk. At time 0, the animals were allowed to move freely in the Petri dish. Each value is the mean of five replicates \pm standard error.

Figure 2. Penicillium spinulosum. See figure 1 legend.

Figure 3. Trichoderma polysporum. See figure 1 legend. 
Table I. Mean ( \pm standard error) number of individuals of Onychiurus sinensis present on each fungal strain over the whole observation period, for three different substrates. Twenty individuals were introduced at the start of the experiment (replicated five times). The duration of the experiment was $3 \mathrm{~h}$. Means followed by letters indicate homogeneous groups (Newman-Keuls test after one-way ANOVA comparing fungal species). Results of $t$-tests were indicated in bold (significantly higher), italic (significantly lower) or normal (insignificant difference) character types or by symbols $(>,<,=)$. See Materials and Methods for more details. Significance thresholds were fixed at $\mathrm{P}=$ 0.05 .

\begin{tabular}{|c|c|c|c|c|c|c|c|c|c|c|c|}
\hline & \multicolumn{3}{|c|}{ Malt-agar } & \multicolumn{4}{|c|}{ Litter disk } & \multicolumn{4}{|c|}{ Filter paper } \\
\hline & On fungus & $\begin{array}{l}\text { In sector } \\
\text { with } \\
\text { fungus }\end{array}$ & $\begin{array}{c}\text { In } \\
\text { sector } \\
\text { without } \\
\text { fungus }\end{array}$ & $\begin{array}{c}\text { On } \\
\text { inoculated } \\
\text { litter disk }\end{array}$ & $\begin{array}{l}\text { In sector } \\
\text { with } \\
\text { inoculated } \\
\text { disk }\end{array}$ & $\begin{array}{c}\text { On } \\
\text { uninoculated } \\
\text { litter disk }\end{array}$ & $\begin{array}{c}\text { In sector with } \\
\text { uninoculated } \\
\text { disk }\end{array}$ & $\begin{array}{c}\text { On odour- } \\
\text { impregnated } \\
\text { filter paper }\end{array}$ & $\begin{array}{c}\text { In sector } \\
\text { with } \\
\text { odour }\end{array}$ & $\begin{array}{c}\text { On } \\
\text { neutral } \\
\text { filter } \\
\text { paper }\end{array}$ & $\begin{array}{c}\text { In } \\
\text { neutral } \\
\text { sector }\end{array}$ \\
\hline $\begin{array}{c}\text { Mucor } \\
\text { plumbeus }\end{array}$ & $\begin{array}{c}14.8 \mathrm{a} \pm 0.5 \\
>\end{array}$ & $16.8 \pm 0.4$ & $3.2 \pm 0.4$ & $17.6 \mathrm{a} \pm 0.7$ & $19.1 \pm 0.3$ & $0.1 \pm 0.04$ & $0.9 \pm 0.3$ & $1.9 \mathrm{c} \pm 0.1$ & $13.5 \pm 1.2$ & $0.1 \pm 0.02$ & $6.5 \pm 1.2$ \\
\hline $\begin{array}{l}\text { Trichothecium } \\
\text { roseum }\end{array}$ & $\begin{array}{c}\text { 13.lab } \pm 0.7 \\
>\end{array}$ & $16.1 \pm 0.7$ & $3.9 \pm 0.7$ & $\begin{array}{c}18.3 \mathrm{a} \pm 0.4 \\
>\end{array}$ & $19.1 \pm 0.3$ & 0.0 & $0.9 \pm 0.3$ & $\begin{array}{c}3.4 a \pm 0.1 \\
=\end{array}$ & $10.8 \pm 0.7$ & $0.2 \pm 0.04$ & $9.2 \pm 0.7$ \\
\hline $\begin{array}{c}\text { Sterile dark } \\
\text { mycelium S18 }\end{array}$ & $\begin{array}{c}12.2 \mathrm{ab} \pm 1.1 \\
=\end{array}$ & $16.9 \pm 0.6$ & $3.1 \pm 0.6$ & $\begin{array}{c}2.5 \mathrm{e} \pm 0.4 \\
=\end{array}$ & $11.6 \pm 0.6$ & $0.7 \pm 0.2$ & $8.4 \pm 0.6$ & $\begin{array}{c}1.8 \mathrm{c} \pm 0.2 \\
<\end{array}$ & $13.0 \pm 0.9$ & $0.3 \pm 0.1$ & $7.0 \pm 0.9$ \\
\hline $\begin{array}{c}\text { Altemaria } \\
\text { alternata }\end{array}$ & $\begin{array}{c}10.3 \mathrm{bc} \pm 1.6 \\
=\end{array}$ & $16.2 \pm 0.8$ & $3.8 \pm 0.8$ & $\begin{array}{c}4.8 \mathrm{~d} \pm 0.3 \\
<\end{array}$ & $12.0 \pm 0.4$ & $0.7 \pm 0.1$ & $8.0 \pm 0.4$ & $\begin{array}{c}1.2 \mathrm{~d} \pm 0.1 \\
<\end{array}$ & $12.3 \pm 1.3$ & $0.3 \pm 0.1$ & $7.7 \pm 1.3$ \\
\hline $\begin{array}{c}\text { Aureobasidium } \\
\text { pullulans }\end{array}$ & $\begin{array}{c}7.6 \mathrm{~cd} \pm 1.2 \\
=\end{array}$ & $16.5 \pm 1.1$ & $3.5 \pm 1.1$ & $\begin{array}{c}6.7 \mathrm{c} \pm 0.6 \\
=\end{array}$ & $14.3 \pm 0.7$ & $0.8 \pm 0.3$ & $5.7 \pm 0.7$ & $\begin{array}{c}1.1 \mathrm{~d} \pm 0.1 \\
<\end{array}$ & $11.9 \pm 0.4$ & $0.3 \pm 0.1$ & $8.1 \pm 0.4$ \\
\hline $\begin{array}{l}\text { Penicillium } \\
\text { spinulosum }\end{array}$ & $\begin{array}{c}7.6 \mathrm{~cd} \pm 1.4 \\
=\end{array}$ & $15.4 \pm 1.0$ & $4.6 \pm 1.0$ & $\begin{array}{c}2.1 \mathrm{e} \pm 0.5 \\
=\end{array}$ & $11.2 \pm 0.4$ & $0.3 \pm 0.1$ & $8.8 \pm 0.4$ & $\begin{array}{c}2.3 \mathrm{bc} \pm 0.3 \\
<\end{array}$ & $15.9 \pm 0.4$ & $0.1 \pm 0.02$ & $4.1 \pm 0.4$ \\
\hline $\begin{array}{l}\text { Cladosporium } \\
\text { cladosporioides }\end{array}$ & $\begin{array}{c}5.8 \mathrm{~d} \pm 0.3 \\
=\end{array}$ & $14.2 \pm 0.9$ & $5.8 \pm 0.9$ & $\begin{array}{c}18.2 \mathrm{a} \pm 0.2 \\
>\end{array}$ & $19.1 \pm 0.2$ & 0.0 & $0.9 \pm 0.2$ & $\begin{array}{c}1.0 \mathrm{~d} \pm 0.1 \\
<\end{array}$ & $13.3 \pm 0.8$ & $0.2 \pm 0.1$ & $6.7 \pm 0.8$ \\
\hline $\begin{array}{l}\text { Epicoccum } \\
\text { purpurascens }\end{array}$ & $\begin{array}{c}5.3 \mathrm{~d} \pm 0.2 \\
<\end{array}$ & $16.3 \pm 0.7$ & $3.7 \pm 0.7$ & $\begin{array}{c}16.1 \mathrm{a} \pm 0.7 \\
>\end{array}$ & $18.2 \pm 0.3$ & 0.0 & $1.8 \pm 0.3$ & $\begin{array}{c}2.6 \mathrm{~b} \pm 0.2 \\
=\end{array}$ & $10.5 \pm 1.1$ & $0.3 \pm 0.1$ & $9.5 \pm 1.1$ \\
\hline $\begin{array}{c}\text { Basidiomycete } \\
\text { S41 }\end{array}$ & $\begin{array}{c}5.0 \mathrm{~d} \pm 0.4 \\
=\end{array}$ & $10.4 \pm 0.9$ & $9.6 \pm 0.9$ & $11.3 \mathrm{~b} \pm 0.4$ & $15.3 \pm 0.3$ & $0.4 \pm 0.05$ & $4.7 \pm 0.3$ & $\begin{array}{c}2.1 \mathrm{bc} \pm 0.2 \\
<\end{array}$ & $10.3 \pm 0.8$ & $0.2 \pm 0.1$ & $9.7 \pm 0.8$ \\
\hline $\begin{array}{l}\text { Trichoderma } \\
\text { polysporum }\end{array}$ & $\begin{array}{c}0.1 \mathrm{e} \pm 0.05 \\
<\end{array}$ & $7.3 \pm 1.0$ & $\begin{array}{c}12.7 \pm 1 \\
0\end{array}$ & $\begin{array}{c}2.0 \mathrm{e} \pm 0.7 \\
=\end{array}$ & $9.9 \pm 0.3$ & $1.6 \pm 0.3$ & $10.1 \pm 0.3$ & $\begin{array}{c}0.3 \mathrm{e} \pm 0.1 \\
<\end{array}$ & $8.2 \pm 0.4$ & $0.4 \pm 0.1$ & $11.8 \pm 0.4$ \\
\hline
\end{tabular}


Table II. Biological parameters (mean \pm standard error) of Onychiurus sinensis cultured at $295 \mathrm{~K}\left(22{ }^{\circ} \mathrm{C}\right)$ for 9 weeks on ten litter fungi. Mean body length of individuals at the beginning of the experiment: $1.36 \pm 0.01 \mathrm{~mm}$. Twenty individuals were introduced (replicated five times). Means are followed by letters indicating homogeneous groups at the 0.05 threshold (Newman-Keuls test after one-way ANOVA). Fungal strains were ranked for each biological parameter (ranks are indicated in parentheses). Sums of ranks allowed to classify fungal strains into three groups (indicated in the left column).

\begin{tabular}{|c|c|c|c|c|c|c|}
\hline & Fungal species & Total number of moults & $\begin{array}{c}\text { Total number of } \\
\text { eggs }\end{array}$ & Mortality & $\begin{array}{l}\text { Final body length } \\
\qquad(\mathrm{mm})\end{array}$ & $\begin{array}{c}\text { Sum of } \\
\text { ranks }\end{array}$ \\
\hline $\mathrm{I}$ & Mucor plumbeus & $105.6 \mathrm{ab} \pm 4.2(3)$ & $63.2 \mathrm{a} \pm 21.7(1)$ & $0.6 b \pm 0.4(4)$ & $2.04 \mathrm{~b} \pm 0.01(2)$ & 10 \\
\hline I & Epicoccum purpurascens & $121.2 \mathrm{a} \pm 7.6(1)$ & $32.4 \mathrm{ab} \pm 7.0(4)$ & $2.0 \mathrm{~b} \pm 0.6(8)$ & $2.33 a \pm 0.04(1)$ & 14 \\
\hline I & Trichothecium roseum & $106.2 \mathrm{ab} \pm 3.9(2)$ & $17.0 \mathrm{~b} \pm 2.9(8)$ & $0.4 b \pm 0.2(2)$ & $1.89 \mathrm{c} \pm 0.02$ & 15 \\
\hline I & Sterile dark mycelium S18 & $87.6 b c \pm 4.5(6)$ & $42.2 \mathrm{a} \pm 5.9$ & $0.2 b \pm 0.2(1)$ & $1.69 \mathrm{ef} \pm 0.02(7)$ & 17 \\
\hline I & Aureobasidium pullulans & $103.2 \mathrm{ab} \pm 4.4(4)$ & $52.6 \mathrm{a} \pm 8.6(2)$ & $1.0 b \pm 0.4(6)$ & $1.72 \mathrm{ef} \pm 0.02(6)$ & 18 \\
\hline II & Alternaria alternata & $78.6 c \pm 4.3(7)$ & $28.8 \mathrm{ab} \pm 5.2(5)$ & $0.6 b \pm 0.4(4)$ & $1.77 \mathrm{de} \pm 0.02(5)$ & 21 \\
\hline II & Penicillium spinulosum & $99.4 b \pm 7.4(5)$ & $25.2 \mathrm{ab} \pm 3.5(7)$ & $1.0 b \pm 0.4(6)$ & $1.81 \mathrm{~d} \pm 0.02(4)$ & 22 \\
\hline II & Cladosporium cladosporioides & $59.0 \mathrm{~d} \pm 3.2(8)$ & $27.8 \mathrm{ab} \pm 5.3(6)$ & $0.4 b \pm 0.7(2)$ & $1.64 f \pm 0.02(8)$ & 24 \\
\hline III & Basidiomycete S41 & $21.8 \mathrm{e} \pm 2.9$ & $0 \mathrm{c}(9)$ & $8.4 \mathrm{a} \pm 1.3(9)$ & $1.43 \mathrm{~g} \pm 0.02(9)$ & 36 \\
\hline III & Trichoderma polysporum & $17.4 \mathrm{e} \pm 1.6(10)$ & $0 \mathrm{c}(9)$ & $9.4 \mathrm{a} \pm 0.9(10)$ & $1.40 \mathrm{~g} \pm 0.02(10)$ & 39 \\
\hline
\end{tabular}


Onychiurus sinensis I Mucor plumbeus (malt-agar)

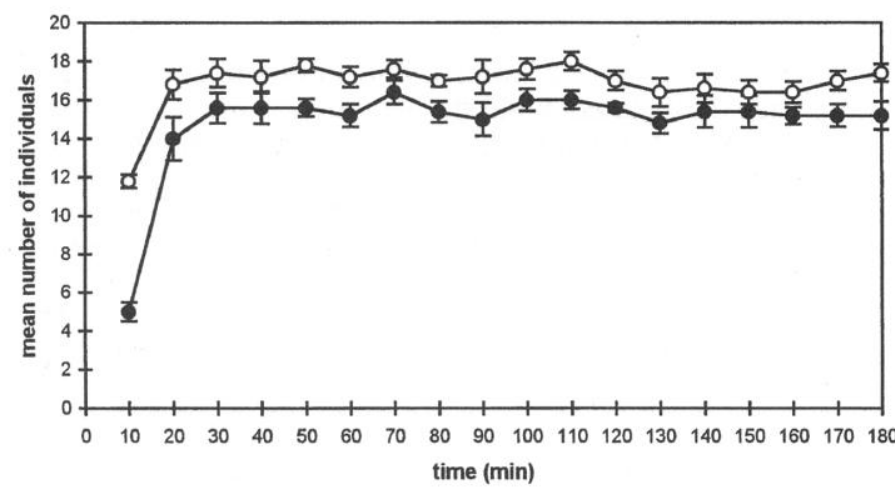

$\rightarrow$ on M.p.

$-\infty$ in M.p. sector

Onychiurus sinensis I Mucor plumbeus (litter)

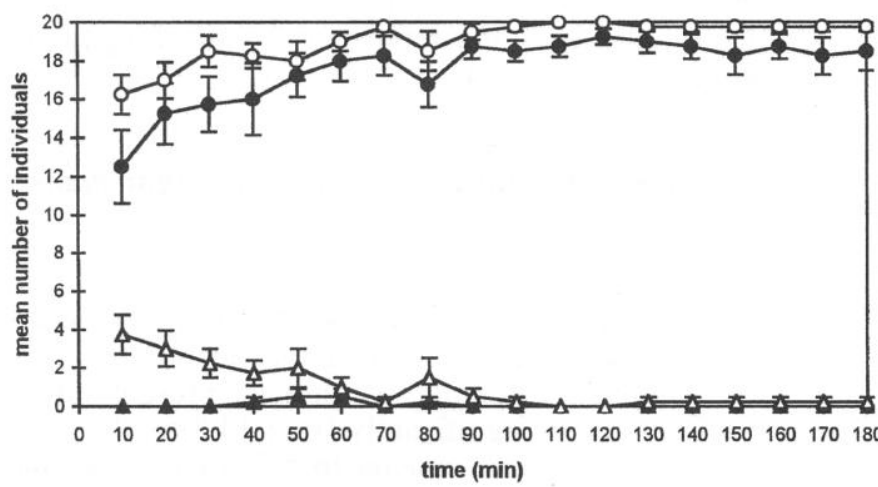

$\multimap-$ on M.p. litter

- - in M.p. sector

$\longrightarrow$ on control litter

$\triangle-$ in control sector

Onychiurus sinensis / Mucor plumbeus (odour)

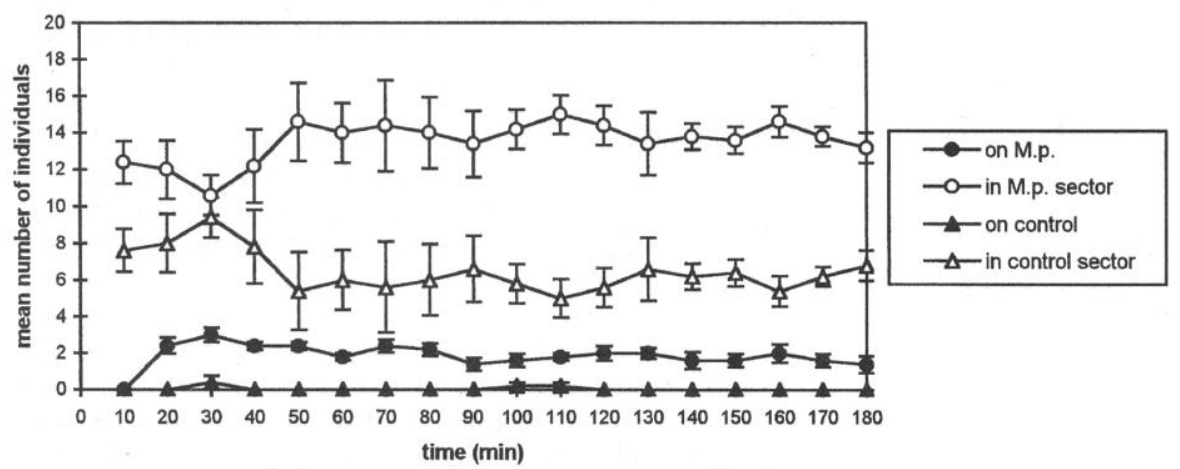

Fig. 1 
Onychiurus sinensis I Penicllium spinulosum (malt-agar)

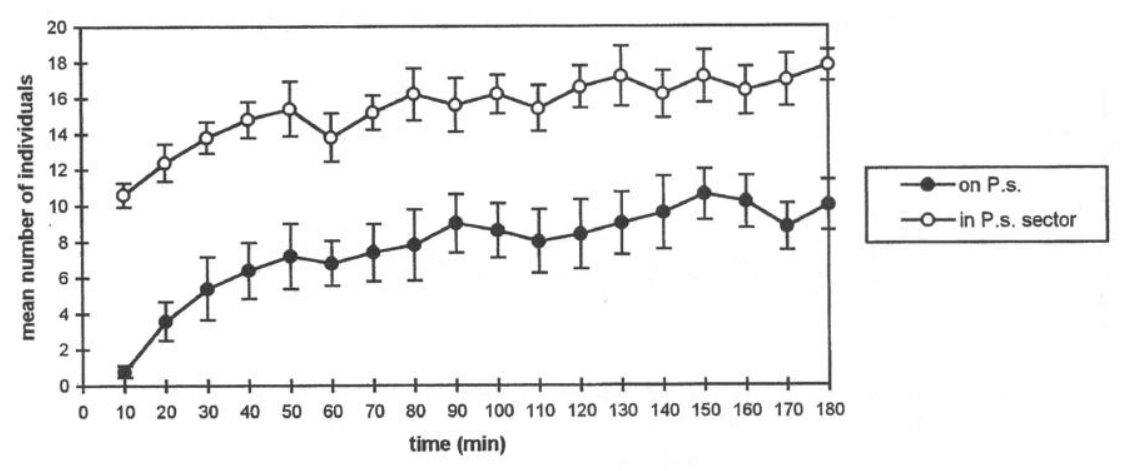

Onychiurus sinensis I Penicillium spinulosum (litter)

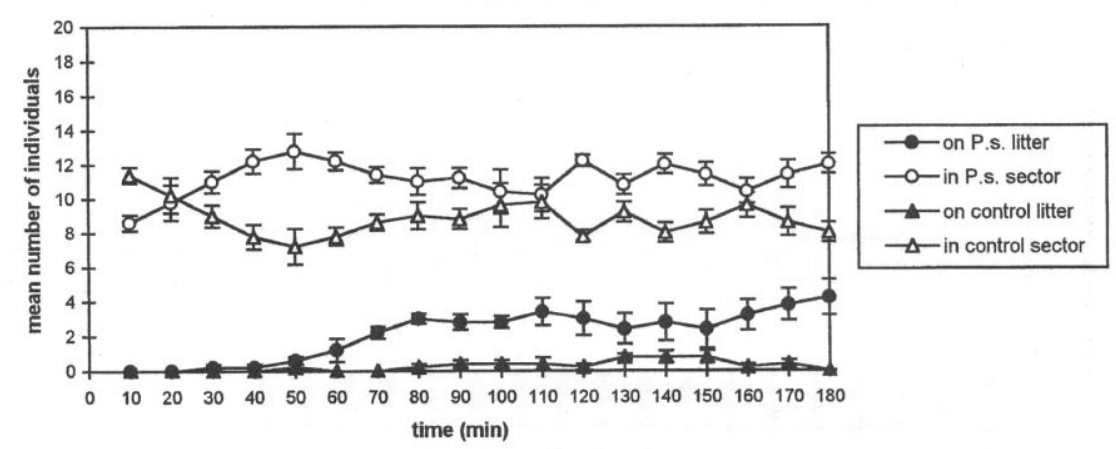

Onychiurus sinensis I Penicillium spinulosum (odour)

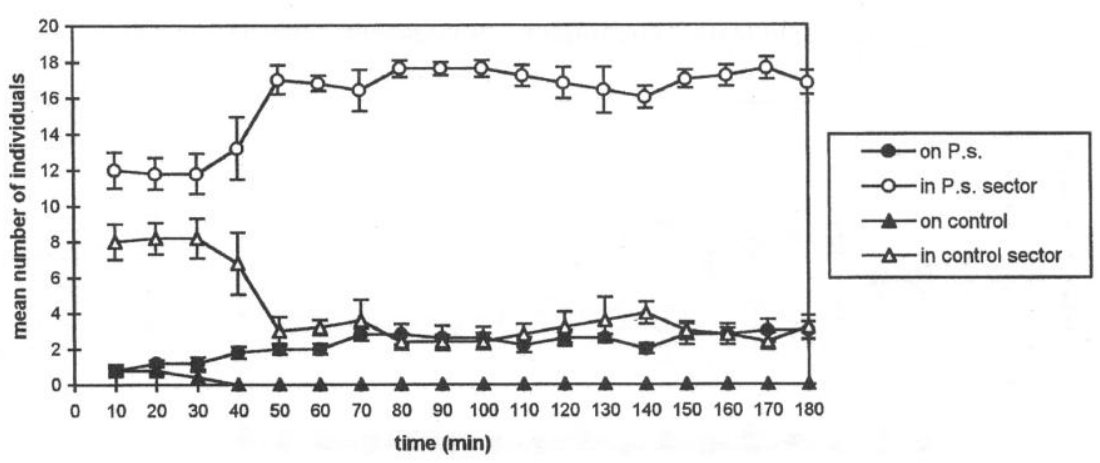

Fig. 2 
Onychiurus sinensis / Trichoderma polysporum (malt-agar)

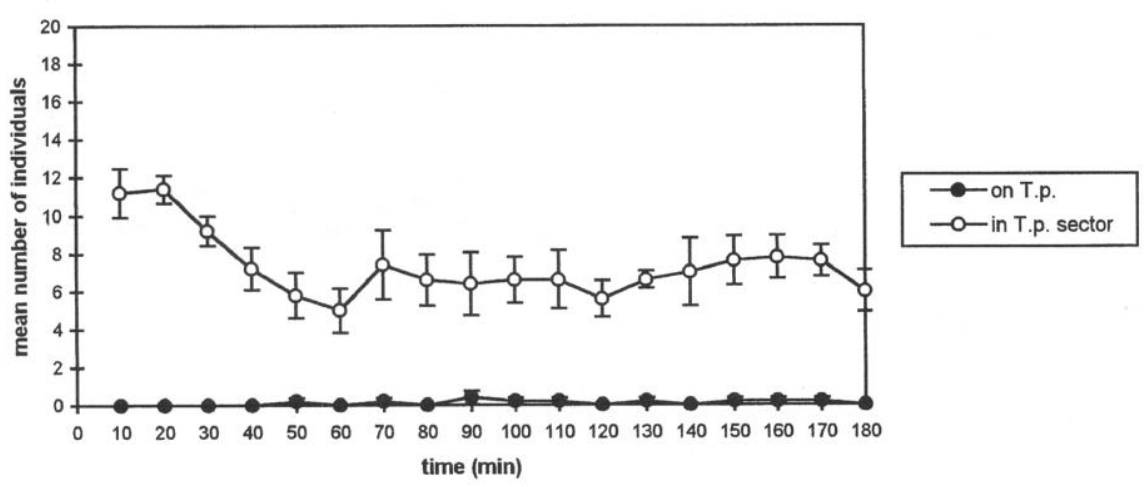

Onychiurus sinensis I Trichoderma polysporum (litter)

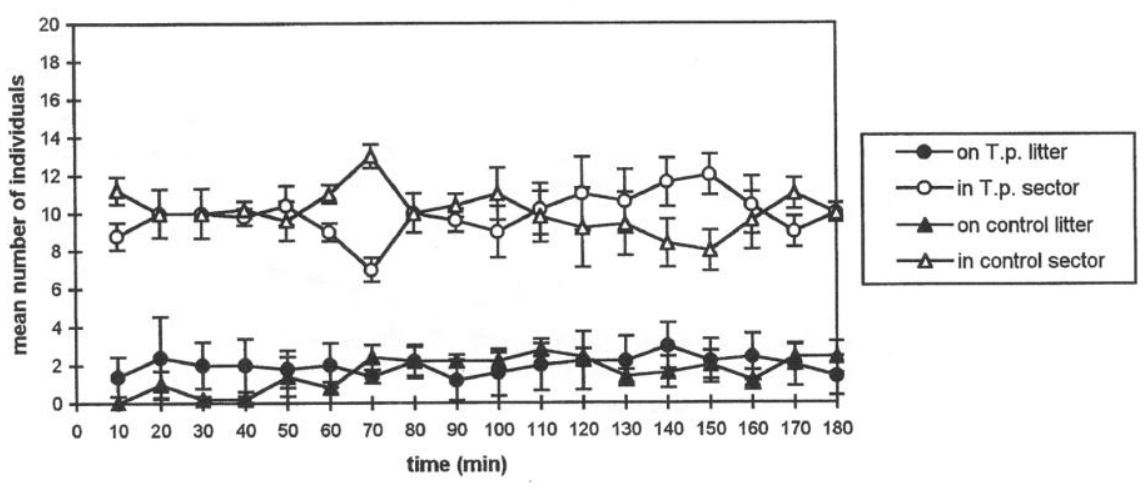

Onychiurus sinensis I Trichoderma polysporum (odour)

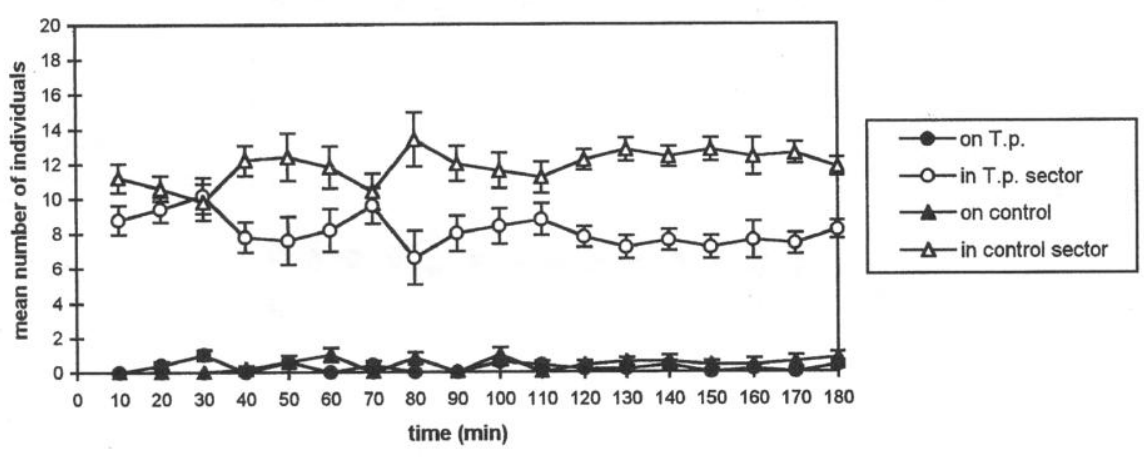

Fig. 3 